\title{
Diurnal Variations in the Total Nitrogen Content of Foliage Leaves.
}

\author{
BY
}

\section{ALBERT CHARLES CHIBNALL. \\ (From the Biochemical Department, Imperial College of Science and Technology.)}

$\mathrm{D}^{\mathrm{u}}$

URING the past two or three years the writer has had occasion to refer to the literature dealing with the nitrogen content of leaves.

It is a subject that has been treated by chemist, botanist, and agriculturist, consequently papers concerning it are scattered in a number of journals of diverse interests, often difficult of access. Czapek (3) has made a praiseworthy effort to collect them, but the limitations imposed on the writer of a handbook such as his have naturally prevented him giving anything but the briefest discussion on the subject-matter contained therein.

In the present paper the author proposes to discuss only one aspect of the subject, that concerning the diurnal variations in the total nitrogen content of leaves. He is prompted to do this because some workers have failed to grasp one significant fact when estimating these variations, namely, that the total nitrogen makes up but a small fraction of the total weight of a leaf, and that the large normal variation in other constituents of the leaf, such as carbohydrates or water, may quite prevent the change in total nitrogen appearing in its true value unless proper allowances are made.

A diurnal change in the nitrogen content of a leaf at night, if it can be definitely established, is a point of physiological interest, in that it may be used as a stepping stone to the elucidation of a complex and important problem that is still more or less a mystery, that of the nitrogenous metabolism in the leaf.

At any moment the total nitrogen content of a leaf depends on the two following variables:

I. The rate of translocation through the petiole into the leaf of simple nitrogenous substances, such as nitrates, ammonium salts, \&c., from the root system.

2. The rate of translocation of nitrogenous substances out of the leaf through the petiole to other parts of the plant. If (I) rises relative to (2) nitrogen will accumulate; whilst if (I) falls relative to (2) nitrogen

[Annals of Botany, Vol. XXXVII. No. CXLVII. July, 1923.] 
will be lost. Now the inward and outward flow of nitrogen through the petiole cannot be tapped, consequently it is impossible, by direct chemical analysis, to determine the nature of the nitrogenous substances that pass out of the leaf. But if it can be definitely established that the total nitrogen in a leaf falls at night, then, by chemical analysis, it may be possible to determine from what substances (such as protein) the outgoing nitrogen has originated. This would be an important advance, for though it is known that the protein is synthesized from nitrates, \&c., translocated from the root system, very little is known as to its function in the leaf cell and the composition and ultimate fate of its degradation products. Such analyses have already been made (Kosutany (6), Suzuki (12), Schulze and Schütz (11), Chibnall (2)), but it is not proposed to discuss them here. Their interpretations depend primarily on the method by means of which the comparison of the day and night leaves have been made. In the following pages these methods are discussed in some detail, and the conclusion is drawn that one of them, that which estimates the nitrogen as a percentage of the dry weight of the leaf, gives an inaccurate and misleading result.

In comparing the day and night samples of leaves three methods have been used to estimate the total nitrogen present, namely, those in which it is expressed as

A. Weight in terms of a certain number of leaves,

B. A percentage of the dry leaf-weight,

C. A percentage of the fresh leaf-weight.

It is proposed to examine each of these in detail to ascertain if the diurnal change given by them is reliable.

Method $A$. If every leaf on a plant was directly comparable with every other, this method would give the absolute diurnal change; but since this is not so the question of sampling errors at once arises. The two workers whose results obtained by this method are discussed later have not determined these. An idea as to their magnitude, in the case of annuals, may be gathered from some experiments made by the present author with the leaves of Vicia Faba maj. Twelve plants, about six weeks after they had appeared above ground, were used. All the leaves from each plant were picked and weighed. Probable errors, calculated by Peter's formula, are given in Table $\mathrm{I}$.

\section{TABLE I.}

Showing Probable Errors of Leaves from Vicia Faba maj.

$\begin{array}{lccc} & \begin{array}{c}\text { Number of } \\ \text { leaves per } \\ \text { plant. }\end{array} & \begin{array}{c}\text { Weight of } \\ \text { leaves per } \\ \text { plant in } \\ \text { grm. }\end{array} & \begin{array}{c}\text { Average } \\ \text { weight of } \\ \text { a leaf in } \\ \text { grm. }\end{array} \\ \begin{array}{l}\text { Mean of I 2 plants } \\ \text { Probable error of the mean of I 2 plants }\end{array} & 35 & 19.75 & 0.574 \\ \text { Percentage error of the mean } & 3.17 & \pm 0.99 & \pm 0.025 \\ & 3.34 & 5.0 & 4.4^{2}\end{array}$


The total number of leaves from the twelve plants was 4I9, of total weight $237 \mathrm{grm}$. For a sample of this size and weight the probable errors in the total nitrogen are given in Table II, the nitrogen being determined by the Kjeldahl-Gunning method modified for the presence of nitrates.

TABLE II.

Showing Sampling Errors in the Total Nitrogen of the Leaves of Vicia Faba maj.

$\begin{array}{lccc} & \begin{array}{c}\text { Weight of } \\ \text { nitrogen }\end{array} & \begin{array}{c}\text { Percentage of } \\ \text { nitrogen per }\end{array} & \begin{array}{c}\text { Percentage of } \\ \text { nitrogen per }\end{array} \\ & \text { per } 100 & \text { total dry } & \text { totalfresh } \\ & \text { leaves. } & \text { leaf-weight. } & \text { leaf-reight. } \\ & \text { (Method A.) } & \text { (Method B.) } & \text { (Method C.) } \\ \text { Mean } & 0.43^{2} & 5.7 \mathrm{I} & 0.753 \\ \text { Probable error } & \pm 0.0195 & \pm 0.036 & \pm 0.0068 \\ \text { Percentage error } & 4.50 & 0.63 & 0.91\end{array}$

The percentage error in estimating the nitrogen by Method A was 4.50 , a figure five times as great as Method $\mathrm{C}$ and seven times as great as Method B. Undoubtedly, if circumstances are such that leaves of similar age and size can be used in the diurnal samples (such as the opposite leaflets of the pinnate leaves of the weeping ash) the probable errors by Method A would be lower, but in the absence of any definite data as to the size of these errors, Method A must be considered inferior to Methods B and $\mathrm{C}$.

Method B. Variation in the total dry weight of a leaf will depend on the assimilation of carbon dioxide from the air, on respiration, and translocation of substances into and away from the leaf through the petiole. If the diurnal variation is estimated over a period of darkness, the assimilation of carbon dioxide will be nil. But of the substances leaving the leaf through the petiole only part, probably a small part, will be nitrogen. Clearly then, when the diurnal change in the nitrogen content of a leaf is being estimated by this method, it is not the absolute amounts of nitrogen in the leaves that are being compared, but only the concentrations of nitrogen in terms of total solids. For example: suppose the percentage loss due to translocation of total solids and total nitrogen away from leaf to be the same, then the percentage of nitrogen per dry weight remains unchanged. Similarly, if the percentage fall in the total nitrogen is greater than that of total solids the percentage of nitrogen per dry weight will fall, whilst if the percentage fall in the total nitrogen is less than that of the total solids, the percentage of nitrogen per dry weight will rise. Obviously this method is quite inapplicable for expressing the true diurnal change in the nitrogen content of leaves, since a loss, should it be proportionately less than that of the total solids, will appear as by a rise.

It is true that Brown and Morris (1), Parkin (9), and Davis, Daish, and 
Sawyer (4) in their estimations of the diurnal change in sugars and starch have all used the percentage dry weight basis. But in these cases it must be remembered that the major part of the loss in total dry weight of the leaf at night is to be ascribed to the translocation of sugars either pre-existing as such in the leaf, or formed during the night by the hydrolysis of starch. Consequently, as starch and sugars make up only 20-30 per cent. of the total dry weight, it follows that the percentage loss in these substances will always be much greater than that of total solids. Their results then, though they show a lesser fall than that which actually occurred, are of the utmost value.

Method $C$. When using this method it is necessary to consider not only changes in the total solids, as has been done above, but in the water-content of the leaf as well. The diurnal change in the water-content of leaves has been the subject of several researches, but only two are worth considering here. Livingston and Brown (7) obtained the water-content of the leaf by drying in an oven at $105^{\circ}$. Analysis of the tables given by them for several different types of plants shows that the chief fluctuation in the water-content took place around midday, when it was natural to expect that the rate of transpiration from the stomata would be a maximum. During the night the leaves remained more or less saturated, and the values that they give for the percentage of water over the hours 6-Io p.m. do not differ by more than I per cent. from those over the hours 3-6 a.m. Their work was carried out in the summer at the Desert Laboratory at Tucson, Arizona, U.S.A., and as they themselves point out, in cooler or more humid climates, such ${ }^{T}$ as are experienced in England or Germany, smaller fluctuations can reasonably be expected.

Knight (5), using the same procedure, has recently demonstrated that this is indeed so, and his figures for Eupatorium adenophorum indicate a change of about $0 . \mathrm{I}$ per cent. between $5.30 \mathrm{p} . \mathrm{m}$. and $8.30 \mathrm{a} . \mathrm{m}$. It is by no means certain, however, that these authors are justified in assuming any change in the water-content of their leaves at all. All that they really show is that there is a change in the dry weight of the leaf expressed as a percentage of the fresh weight. This may well be brought about by translocation of solids away from the leaf, for Parkin's (9) work on the snowdrop and Davis, Daish, and Sawyer's (4) on the marigold both show a fall in total sugar at night of 3 per cent. of the dry weight, equivalent to about 0.5 per cent. of the fresh weight of the leaf. It would appear, then, that the only conclusion to be drawn from these results is that the variation in the watercontent of the leaf at night must be very small. This view is confirmed by another observation of Knight's (5). He removed a series of leaves from a plant and allowed them to wilt for ten, twenty, and thirty minutes respectively before weighing for water determinations. In these cases no translocation of solids away from the leaves was possible, consequently his obser- 
vation, that extreme flaccidity results in a decrease of approximately only I per cent. of the water-content of a leaf, shows that the diurnal variation must be extremely small. Now water makes up 80 per cent. to 90 per cent. of the total weight of most fresh leaves. It would appear then that the diurnal change in the total nitrogen, expressed by Method C, will approximate very closely to the actual diurnal change in the leaf. It has already been pointed out that Method A expresses this also, but that the sampling errors, as shown in Table II, are greater. Method C, then, seems the best to adopt as a working basis.

It is now proposed to examine some of the published results in detail.

Schulze and Schütz (11) These workers have made a very thorough investigation into the seasonal and diurnal changes in the leaves of Acer negundo. The leaves were picked from two trees fifteen to twenty years old, and those in each sample were chosen as far as possible of equal weight and size. The evening leaves were picked between 6 p.m. and 6.30 p.m., those on the following morning (except in case of 3-6 September) between 5 a.m. and 6.30 a.m. depending on the season. Their results, in so far as they concern the diurnal change in the total nitrogen, are given in Table III. The authors themselves used Methods A and B; it is possible from the data they give to calculate $\mathrm{C}$.

\section{TABLE III.}

Showing the Fall in the Nitrogen Content of the Leaves of Acer negundo at Night, expressed as a Percentage of Day Vahue.

(Schulze and Schütz)

\begin{tabular}{|c|c|c|c|}
\hline Date of Picking. & Method $A$. & Method $B$. & Method $C$. \\
\hline May & 10.16 & $\begin{array}{l}4.50 \\
2.08\end{array}$ & $\begin{array}{l}9 \cdot 07 \\
6.88\end{array}$ \\
\hline 6 June & $\begin{array}{l}9 \cdot 99 \\
7 \cdot 27\end{array}$ & $\begin{array}{l}2.08 \\
1 \cdot 76\end{array}$ & $\begin{array}{l}0.00 \\
1 \cdot 48\end{array}$ \\
\hline 2 Aug. & 3.97 & 0.16 & $-\mathrm{I} \cdot 76$ \\
\hline 3-6 Sept. & $18.5^{\circ}$ & $0.7^{8}$ & II .90 \\
\hline 25 Sept. & $-7 \cdot 54$ & $1 \cdot 36$ & $-7 \cdot 18$ \\
\hline
\end{tabular}

These figures are probably the best available at the present. In the absence of sampling errors those under Method A must be accepted with caution. Method $\mathrm{C}$ shows that when the leaves are young there is a large withdrawal at night, the amount decreasing as the leaf ages until it reaches a value of only I per cent. The apparent large gain at night observed on Sept. 25 may be due to dehydration, as the leaves at that date had already begun to fall. It will be observed from Method $B$ that the loss of nitrogen at night was proportionately greater than that of other solids in the leaf.

Suzuki (12) has examined the diurnal changes between 6 p.m. and 6 a.m. of the plants given in Table IV, the figures in round brackets after each name denoting the number of leaves per sample used. 
TABLE IV.

Showing the Fall in the Nitrogen Content of Leaves of Various Plants at Night, expressed as a Percentage of the Day Value.

(Suzuki)

\begin{tabular}{l}
\multicolumn{1}{c}{ Name of Plant. } \\
Wisteria brachybotrys (400) \\
Phaseolus vulgaris (50) \\
", mungo (200) \\
Pueralia Thunbergiana (5I) \\
Solanum tuberosum (220) \\
Batatas edulis ( 100$)$ \\
Polygonum fagopyrum (450) \\
Helianthus annums (33)
\end{tabular}

$\begin{array}{rc}\text { Method } A . & \text { Method } B . \\ \text { I } 3.6 & -\mathrm{I} .45 \\ 4.3 & 0.0 \\ \text { I0.9 } & -2.24 \\ 4.8 & \mathrm{I} .39 \\ 8.4 & -28.2 \\ 4.0 & -1.33 \\ 8.3 & -3.82 \\ 9.7 & -2.09\end{array}$

Sufficient details are not given for the fall by Method $\mathrm{C}$ to be calculated. Futhermore there is no mention that any regard has been paid to sampling errors. In view of the percentage error of 4.5 quoted above for Vicia Faba Suzuki's results by Method A must be considered inconclusive. It will be noted that Method $\mathrm{B}$ shows in most cases a gain at night, probably indicating nothing more than a large translocation of sugars.

Kosutany (6) has taken a series of diurnal readings for the nitrogen content of the leaves of Vitis riparia. The vine was so placed that it was in the shade after 2-3 p.m. At 3 p.m. one-half of a certain number of leaves was removed by cutting alongside the mid-rib, the other half being removed at 3 a.m. the following morning. He expressed his results by Methods $\mathrm{B}$ and $\mathrm{C}$ (summarized in Table V), but drew all his conclusions from the former.

\section{TABLE V.}

Showing the Fall in the Nitrogen Content of the Leaves of Vitis riparia at Night, expressed as a Percentage of the Day Value.

(Kosutany)

$\begin{array}{rcc}\text { Date picked. } & \text { Method B. } & \text { Method C. } \\ \text { 4-5 June } & -\mathrm{I} \cdot \mathrm{I} 5 & 0.0 \\ \text { 19-20 June } & -2.80 & 7.68 \\ \text { 3-4 July } & -\mathrm{I} .62 & -5.99 \\ \text { 4-15 Aug. } & -\mathrm{I} .66 & -0.7 \mathrm{I} \\ \text { 28-29 Aug. } & -\mathrm{I} \cdot 42 & 7.84 \\ \text { 25-26 Sept. } & -2.03 & 4.86 \\ \text { 9-10 Oct. } & -2.74 & 4.20\end{array}$

He therefore stated that leaves became enriched with nitrogen during the night, and concluded, from further analyses, that this was due to the accumulation of protein. In light of the discussions given above it will be seen that this conclusion is not justified. By Method $\mathrm{C}$ there is in four cases a fall, in one no change, in one a very small rise, and in one only any evidence of a pronounced rise. 
Otto and Kooper (8) have made a careful examination of the morning and evening nitrogen content of the leaves of Aesculus hippocastamum, Philadelphus coronarius, Phlox Drummondi, Sambucus nigra, and Syringa vulgaris. Leaves were picked at 6 p.m., and at 6 a.m. the following morning, at frequent periods throughout the season. Samples were picked with care from plants of the same age. They express their results by Method B, showing in all cases a very small fall in the nitrogen content at night. As it is impossible to believe that the leaves become richer in sugars, \&c., through translocation into the leaf, their results undoubtedly do indicate a fall in the nitrogen at night. But it would appear that the authors did not completely realize that they were only comparing relative concentrations in terms of total solids, as mentioned earlier on page $5^{13} 3$. Unfortunately Otto and Kooper do not give the fresh weight of the leaves used, so that an estimate of the actual fall in the nitrogen content at night cannot be calculated by Method C. Their results, then, though they undoubtedly indicate a fall in the nitrogen at night, do so only because in the samples examined the loss of nitrogen happens to have been greater than that of sugars, \&c.

Pigorini's (10) results for the mulberry, with samples picked at 5 p.m. September 7 and 5 a.m. the following morning, show a fall at night by Methods B and C, whilst those of the present author (Chibnall (2)), for Phaseolus vulgaris var. multiflorus, for samples picked $8.3^{\circ}$ p.m. July 3 and 2.I 5 a.m. July 4, each consisting of all the leaves from I2 plants, show a rise by Method B, and a fall by Method C.

Reviewed as a whole the results quoted above undoubtedly establish the fact that in general there is a withdrawal of nitrogen from the leaves at night. Schulze and Schütz show that for trees the amount decreases as the leaf ages, but, though one would expect the same for annuals, no evidence has yet been presented.

\section{LITERATURE CITED.}

1. Brown, H. T., and Morris, G. H. : A Contribution to the Chemistry and Physiology of Foliage Leaves. Journ. Chem. Soc., I 893 , lxiii. 604-83.

2. Chibnall, A. C. : Investigations on the Nitrogenous Metabolism of the Higher Plants. II. The Distribution of Nitrogen in the Leaves of the Runner Bean. Biochem. Journ., I922, xvi. $344-62$.

3. CzapeK, F. : Biochemie der Pflanzen, vol. ii, I920.

4. Davis, W. A., Daish, A. J., and Sawyer, G. C. : Studies of the Formation and Translocation of Carbohydrates in Plants. I. The Carbohydrates of the Marigold Leaf. Journ. Agric. Sci., I916, vii. $255-326$.

5. Knight, R. C. : Further Observations on the Transpiration, Stomata, Leaf Water-content, and Wilting of Plants. Ann. Bot., 1922, cxliii. 361-83. 


\section{I 8 Chibnall.-Variations in Nitrogen Content of Foliage Leaves.}

6. Kosutany, T.: Untersuchungen über die Entstehung des Pflanzeneiweisses. Landw. Vers.Stat., 1 897 , xlviii. 1 $3-32$.

7. Livingston, B. E., and Brown, W. H. : Relation of the Daily March of Transpiration to Variations in the Water-content of Foliage Leaves. Bot. Gaz., I9r 2, liii. 309-30.

8. OTto, R., and Kooper, W. D.: Beiträge zur Abnahme bezw. Rückwanderung der Stickstoffverbindungen aus den Blättern während der Nacht, sowie zur herbstlichen Rückwanderung von Stickstoffverlindungen aus den Blättern. Landw. Vers.-Stat., I9I0, xxxix. $167-72$.

9. Parkin, J.: The Carbohydrates of the Foliage Leaf of the Snowdrop (Galanthus nivalis, L.) and their Bearing on the First Sugar of Photosynthesis. Biochem. Journ., I91 I, vi. I-47.

10. Pigorini, L. : Studi sulla foglia di gelso: sulla composizione chimica della foglia al mattino e alla sera. Atti dei Lincei, I9 4 , (5), xxiii. (2) 433-7.

11. Schulze, B. (ref.), and Schütz, J.: Die Stoffwandlungen in den Laubblättern des Paumes, insbesondere in ihren Beziehungen zum herbstlichen Blattfall. Landw. Vers.-Stat., 1909, 1xxi. $299-35^{2}$.

12. Suzuki, U.: On an Important Function of Leaves. Bull. Coll. Agric. Tokyo, 1897, iii. $24 \mathrm{I}-5^{2}$. 


\section{$2 \mathrm{BHL}$ Biodiversity Heritage Library}

Chibnall, Albert Charles. 1923. "Diurnal variations in the total nitrogen content of foliage leaves." Annals of botany 37, 511-518.

https://doi.org/10.1093/oxfordjournals.aob.a089863.

View This Item Online: https://www.biodiversitylibrary.org/item/270686

DOI: https://doi.org/10.1093/oxfordjournals.aob.a089863

Permalink: https://www.biodiversitylibrary.org/partpdf/319099

\section{Holding Institution}

New York Botanical Garden, LuEsther T. Mertz Library

\section{Sponsored by}

BHL-SIL-FEDLINK

\section{Copyright \& Reuse}

Copyright Status: Public domain. The BHL considers that this work is no longer under copyright protection.

This document was created from content at the Biodiversity Heritage Library, the world's largest open access digital library for biodiversity literature and archives. Visit BHL at https://www.biodiversitylibrary.org. 